\title{
INTRODUCTION: EXPLORING THE MATERIALITY OF FOOD‘STUFFS’: TRANSFORMATIONS, EMBODIMENT AND RITUALIZED CONSUMPTION
}

Louise Steel and Katharina Zinn

\section{INTRODUCTION}

'Food touches everything. Food is the foundation of every economy. It is a central pawn in political strategies of states and households. Food marks social differences, boundaries, bonds, and contradictions. Eating is an endlessly evolving enactment of gender, family, and community relationships'

(Counihan and van Esterick 1997, 1)

This volume - which has grown out of two workshops ${ }^{1}$ examining the materiality of foodstuffs past and present - sets out to explore people's intriguingly complex, shifting relationships with, and experiences of, the materialities of 'foodstuffs'.

Both in contemporary contexts and in remote antiquity, food and the 'stuff' of food - is central to people's daily experiences, as it is to social reproduction, and their sense and expression of identity. Myriad aspects of the materiality of food, and how it is socialized, have been extensively researched by both anthropologists and archaeologists. Within anthropology, the emphasis has been on the actual food, in particular highlighting its symbolic meaning (Lupton 1994; Miller 1998; Mintz and du Bois 2002) and its place within the political economy (Mintz 1985; Watson and Caldwell 2004). More recently there has been increasing emphasis placed on the relationship between the human body and edible substances; there is a focus on the physical transformative relationship between people and the food they eat - how the biological act of ingestion makes and transforms a body (cf. Lupton 1996; Hayes-Conroy and Hayes-Conroy 2008; Mol 2008; Lavis in press). This perspective is increasingly informed by the agency of food, the concept of edible matter as actant (cf. Bennett 2010, 39-51). The visceral sensuality of food, as well as the importance of taste and smell in constructing memory and meaning, comprises another fruitful area of enquiry (Lupton 1994; Sutton 2001; Holtzman 2006; see also Wilk, this volume). 
In contrast, the material culture of food (and drink) tends often to be overlooked by anthropologists. The materialities of the 'stuff' of food - the objects used to prepare, wrap, serve and consume food and the tactile experiences involved in its production and consumption - have tended to be tangential to anthropological enquiry. The focus has rather been on the substances ingested rather than the embodied actions embedded in the preparation, storage, presentation, consumption and discard of food as well as the objects thereof.

Archaeological studies have engaged more explicitly with the material culture of food and drink, as much as with the substances consumed; the latter are increasingly being woven into narratives of past cultures through the rich data evidenced by palaeobotany (cf. Tzedakis and Martlew 1999), faunal remains (cf. Miracle and Milner 2002) and residue analyses (cf. Tzedakis and Martlew1999; McGovern 2003; 2009). These scientific analyses are primarily directed towards the identification of ancient diet and the physicality of food (Ryan et al. 2012; Ryan and Spencer 2013). Another productive area of enquiry has focused on storage strategies, especially those embedded in emergent political systems (cf. Wesson 1999; Christakis 2011), but equally those within the household (Christakis 1999; Steel in press). An additional area which has received considerable attention is the political significance of sharing food; there has been some discussion on ritualized consumption (Steel 2004; Blake 2005) and the dialectics of feasting (Dietler 1996; Hayden 1996; Dietler and Hayden 2001; Bray 2003; Hayden 2014). On the other hand, there has been rather less emphasis on the embodied experience of the consumers, to a certain extent no doubt, reflecting the temporal distance of the researcher from their object(s) of study. The sensuality of consumption, notably the use of food and foodstuffs in the creation and fostering of embodied memory, has received limited attention (Hamilakis 1998; 2008; Hamilakis and Sherratt 2012). Likewise, with rare exceptions such as Stockhammer's (2012) discussion of culturally situated handling of drinking vessels, the cultural practices and embodied physical acts involved in the consumption and actual experience of foodstuffs remain elusive.

Our book aims to challenge this perceived intellectual dichotomy by bringing together researchers from various fields of food history such as Chinese Studies and Egyptology, as 
well as archaeology and anthropology. The workshops referred to earlier, involving individuals of differing interests and experience, culminated in a vibrant and refreshing discussion. We trust that the variety and enthusiasm the participants of the workshop(s) brought to that debate is roundly demonstrated through the spirit of this volume as well as within their respective chapters.

The book as a whole sets out to explore people's embodied engagement with food and the material culture that accompanies the production, consumption and socialization of food both within contemporary cultures and in ancient communities. Rather than simply reiterating the symbolic meaning(s) of food and its role as a social actant, the individual chapters focus on the material characteristics of foodstuffs and their associated objects. The aim is to build upon existing dialogues concerning the materiality of food by interweaving strands which focus equally on the properties and agency of the diverse substances consumed by people, with the materiality of the objects used in the production, distribution and consumption of edible matter.

The golden thread running through this volume is the material culture of food and drink. Objects are central to the production, distribution and consumption of foodstuffs, be they grinding stones, containers (basketry, pottery, cans and Tupperware), cooking equipment and implements, or branded food wrappings, to name just a few examples. These artefacts are entangled within daily experiences of foodways; they mediate - as much as they are mediated by - people's embodied engagements with the food consumed and the places where these foodstuffs are produced, prepared, exchanged and consumed. In this volume the entanglement of objects, consumables and people is illustrated by a number of case studies, which variously demonstrate how a myriad objects are, and have been, used to process, package, store, advertize, serve and consume food, and moreover, how these various activities are central to the creation and reproduction of social worlds.

The materiality of these foodstuffs is explored through the lens of three key interconnected conceptual themes: transformations (Part One), embodied encounters (Part Two) and symbolic consumption (Part Three). These three leitmotifs are not exclusive, but mutually beneficial; most of the presented chapters could also easily have been placed within at least 
one other category: Attala (Part One) in addition to the transformations made possible by exploring water flows also describes manifold embodied encounters with this substance, while Forde likewise describes the inherent transformative character of the application of permaculture even though her main focus lies with embodied encounters. Equally, depositional contexts as specified by Reinhart (Part Three) not only reflect symbolic consumption of foodstuffs, but also the transformation of the deposit (area) over a certain time. The placement of the particular papers into the three sections therefore reflects both the broadness of the topic as well as the personal choice of the editors.

Our case studies are drawn from a range of geographical and historical contexts, with the expressed intention of fostering debate and ensuring that discussion does not become fixed within esoteric or regionalist debates.

\section{TRANSFORMATIONS}

In Part One: Transformations we consider various ways in which foodstuffs and their associated material culture might be transformed. Our starting point is the notion of 'making' (Ingold 2013) and the actual production of cuisine; the transformation of edible substances from raw, unprocessed ingredients to a meal, something that is socialized and to be consumed. We also explore changing social and material practices surrounding the production and consumption of food and drink and how these have radically altered the landscape of eating and drinking, both in remote antiquity and in the very recent past. Ryan, Verriet and Hayden illustrate how the technologies of food production, preparation and consumption are (and have been) continually changing and being transformed. Shifting patterns in the types of materials and objects used to produce, package and serve food ultimately result in altered embodied knowledges and experiences of that food, a process which shapes choices of what food-stuffs' people consume, how they utilize these foods and the social environments in which this is done. Particular attention is given to the ways in which new behaviours and ways of doing things become embedded within society. In a number of case studies therefore, we examine how the development of new technologies, from grinding stones in the Epipaleaolithic to the development of canned and frozen foods in the nineteenth and twentieth century respectively, inevitably affected people's relationships 
with the food they eat, and resulted in various new social practices. This sheds light on how transitions, discontinuities and changes in the material culture of food, food environments and cultural knowledges are variously interpreted and experienced.

Ryan explores the transformation of raw plant materials into cuisine. Her focus is the ancient Egyptian diet from the surviving archaeobotanical evidence; charred macros and phytoliths, from Amara West (Nubia), revealing the basic ingredients of the ancient Egyptian diet, rather than the finished foodstuffs consumed within a meal. Amara West also throws light on the transformation of these plant products in the daily production of food at the site, in the form of a rich material culture dataset, comprising grinding stones, cereal grinding emplacements and bread ovens. The materiality of ancient Egyptian food production, such as crop cultivation and the transformation of foodstuffs into the basics of daily foodways, is enhanced by reference to ethno archaeological research carried out by Ryan in the Nubian villages on nearby Ernetta Island. Intriguingly, this study has thrown light on another transformation faced by food producers in the region in recent decades, impacting upon food procurement strategies and dietary practices - that of environmental change.

Verriet moves the focus of enquiry from the transformation of edible commodities to the people's mutable relationship with the material culture of food-wrappings, packaging and the presentation of these in the media. He examines changing food technologies during the twentieth century, namely the 'domestication' of canned food, in particular shifting perceptions of the can in the Netherlands during the mid-twentieth century. Verriet provides detailed analysis of how this type of packaging was variously advertized and promoted to consumers, in an attempt to inveigle the product into the household. He describes the social process by which canned foods became an ordinary, accepted part of a household's foodstuff as 'domestication': the integration of new food technology into daily life. His findings provide an insight into 'domestication strategies', oft exploited by manufacturers and the role that these play in the creation and/or manipulation of people's perception of a physical object to illustrate how consumer needs and perceptions of foodstuffs evolve over time, ironically eventually resulting in the pedestrianization of the commodity. 
Transformations in the material culture of food, and as a corollary the inevitable impact on the construction of social worlds, are explored within a very different cultural and temporal environment by Hayden et al. Building upon an earlier study of Natufian grinding stones and the development of beer as an intoxicating beverage for feasting within the first sedentary communities of the Levant (Hayden, Canuel and Shanse 2012), in this volume Hayden et al. further investigate the development of new grinding equipment for processing grains in the Epipalaeolithic Levant to produce specialist foods (namely beer and bread) for feasting. This chapter thus provides an important insight not simply on the development of new technologies for processing foodstuffs but equally how the creation of a new cuisine helped mould new social practices which transformed human relations (cf. Hayden 2014).

The final chapter in Part One: Transformations looks specifically at the challenge faced by communities in rural Kenya of living in a radically changing environment, one that is characterized by increasing desertification and the ever-present threat of harvest failure. Rather than the more usual range of foodstuffs, Attala focuses her enquiry on water, not only the staple of food production and but also essential to sustain the human body and that of the plants and animals consumed by people. At the heart of this chapter is an understanding of the agency of water, explored within the intellectual framework of the New Materialisms (Bennett 2010; Coole and Frost 2010). Attala presents a troubling picture of the global water situation and in the context of her case study how, as a result of climatic change, the lives of the Giriama of Kenya are moulded and transformed through their changing relationships with, and understanding of, water.

\section{EMBODIED ENCOUNTERS}

Through a diverse series of case studies, Part Two: Embodied Encounters moves the discussion along by investigating the material experiences involved in the production and consumption of food and drink. It considers a number of distinct corporeal relationships between the people producing, processing and consuming foodstuffs and the substances which they handle, ingest and consume, an aspect as we have seen, that is often neglected. In addition, it investigates the materials and objects through which these relationships are mediated and the haptic relationship between people and the material culture, the "working 
tools' they use to process, store and consume foodstuffs. This approach is suitably informed by Bourdieu's ([1972] 1977) notion of habitus - culturally engrained practices, including body knowledges and the handling of objects that shape people's daily foodways (see in particular Allison). Embodiment also encompasses the interaction between body, mind and stuffs, specifically how foods shape, mould and form mind and body (see Jansen this volume). The focus of this section therefore, is on people's physical engagement with the 'things' of food, an approach that fosters images of the 'hands on' part of the interaction, whilst looking at practical methods, this part evokes investigation and the interpretation of these embodied practices within ancient, historical and contemporary contexts.

The physical, emotional and spiritual consequences of eating form the subject of Jansen's reinterpretation of the Chinese legend of Princess Miaoshan. Through the lens of ritual practice and dietary prohibitions he explores how the biological act of ingestion makes and transforms the body and as a consequence people's experience of the world around them. Jansen moves the debate beyond the material, bodily experience of food to a consideration of its capacity to alter our mental and spiritual state. He further highlights how food, as something that is experienced very differently (bodily and conceptually) by men and women - is intimately intertwined with gender relations.

Forde's analysis engages with the materiality of agricultural production, focusing specifically on permaculture as it is practised at eco-villages in West Wales. Forde proposes that permaculture represents a sustainable food technology. Situated within the intellectual framework of the New Materialisms (Coole and Frost 2010) and the more-than-human debate, she explores the interrelatedness of multiple natural substances and how these are intertwined within material practice in daily life as well as within broader geopolitical and socioeconomic structures. The centrality of the human is overturned with an emphasis on the agency of nature and the vitality of the environment.

Malleson explores agricultural production from the perspective of logistics involved in feeding the pyramid builders of Old Kingdom Egypt. Her approach is embedded in an understanding of human physiology and nutrition; the aim is to provide a working model of 
the logistics by which the pyramid workers were provided with their daily bread, focusing on the carbohydrate requirements of the Heit el-Ghurab workers' settlement on the Giza plateau. Malleson draws upon a variety of data to throw light on the materiality of ancient bread production; these include osteoarchaeological studies of Old Kingdom cemeteries, archaeobotany from Heit el-Ghurab and the associated archaeological evidence for baking and storage facilities at the site, experimental archaeology and ancient Egyptian texts that documented agricultural production and rationing.

The negotiation of daily household experiences of foodways at Pompeii is the focus of Allison's chapter. Situated within a detailed analysis of household spaces and also the material culture of food and drink, she explores how embodied daily consumption of foodstuffs comprise an integral element in social reproduction - namely the creation and perpetuation of social mores and codes embedded in diverse social relations (gendered, status etc.). Not only does this paper throw light on daily consumption practices within the Roman private household, but also how we can extrapolate this approach to the embodied materiality of foodstuffs to better understand status and gender relations in other (archaeological, historical and anthropological) contexts.

\section{SYMBOLIC CONSUMPTION}

Our final section, Part Three: Symbolic Consumption, looks at special(ized) foods and objects of foods and how these are manipulated within symbolic, ritualized practices. While the challenges of changing environments, foodstuffs and material cultures of food (as discussed in Part One: Transformations) and people's embodied interactions with the stuff of food (cf. Part Two: Embodied Encounters) are themes that are meaningful to a modern western audience, special foods and (alcoholic) drinks are so readily available within western society that the notion of limited access to these substances and socialized significance of largesse have become largely alien concepts. Nonetheless, the importance of food as a source of power has been extensively explored in previous studies (cf. Dietler and Hayden 2001; Hayden 2014). Mauss ([1925] 1990) famously situated exchanges of food and drink at the heart of gift exchange; this theme has become embedded in archaeology's understanding of the disbursement of food and drink, in particular sumptuous feasts within chiefdoms and 
early states, as a means of constructing and legitimizing political and ideological power (Schmandt-Besserat 2001; cf. Wright 2004; Hayden 2014, 233-346). As noted by d'Anna $(2012,99)$ 'through feasts, as ritualized events in which food and drinks are shared, food is a means of marking and reproducing social identities and, potentially, inequality'. More recently anthropological studies have emphasized hospitality, rather than gifting, as a way of understanding entertainment and the sharing of foodstuffs with individuals who do not count amongst members of the household (Candea and da Col 2012, esp. 55-6). The theme of special foods (and material cultures of food), which encode symbolic meaning, bubbled to the surface on several occasions within the original Foodstuffs workshop. However, although the seminal work on feasts (Dietler and Hayden 2001) drew upon several ethnographic studies, increasingly anthropologies of food are situated in embodied encounters with foodstuffs rather than the politics of feasting. Consequently, the papers in this section are drawn from a number of archaeological examples, all of which nonetheless, are informed by anthropological understandings of the stuff of food. ${ }^{2}$

Steel examines the material culture of feasting - the eating/drinking vessels and serving equipment - used in ancient Mesopotamia during the third millennium BC. Her focus is on the crafting of enchanted objects specifically for high-status consumption. She considers the physical properties of luxurious materials as vibrant matter (Bennett 2010) and how these are manipulated to enchant the viewer as well as participant. Steel goes on to demonstrate how shared embodied knowledges of how to handle these objects (cf. Stockhammer 2012), the sensorial aspects of the feast (cf. Hamilakis 2008; Hamilakis and Sherratt 2012), shared registers of value and the creation of a shared cultural milieu throughout the region ultimately shaped the material and metaphysical worlds of the Near Eastern elites

Zinn moves beyond the feast as a tool for understanding special foodstuffs, to consider magical substitutes for food, and non-consumption within funerary ritual in ancient Egypt. She focuses on a single object type - a miniature ceramic food-offering vessel commonly used to supply tombs with food for the afterlife or otherwise used as a votive at pilgrimage sites such as Abydos. Food offering as both material and practice played a central role in ancient Egyptian funerary beliefs; Zinn explores how substitutes for real foodstuffs, in the 
form of models, depictions and miniature food vessels were incorporated into this practice through the application of 'magic'.

An alternative perspective to the materiality of symbolic foodstuffs is presented by Collard, who focuses on the ingestions of mind-altering substances (namely opium) in Late Bronze Age Cyprus as part of religious and funerary ritual, with the aim of achieving an altered state of consciousness. His focus is on the material evidence for this practice in the form of various types of containers specifically designed to hold opium. In particular Collard emphasizes how these containers are frequently designed to mimic the poppy head that is the source of the opium, as a form of 'prehistoric commodity branding' (Wengrow 2008) aimed at a presumably largely non-literate community.

In the final chapter of Part Three Reinhart considers how people managed the debris of ritualized consumption with specific reference to Chinese Bronze Age site of Yanshi Shangcheng and a series of pits, ditches and wells that contained significant quantities of pottery, animal bones and ash. Drawing on a growing body of literature on the specialized deposition of ritual deposits Reinhart reassesses the material from Yanshi, questioning whether this can be related to structured deposition of foodstuffs associated with ritual practices, in particular sacrifice and feasting. She concludes that the remains of daily life and ritual action were 'blended' in all types of deposition and that thus the distinction between the metaphysical and material worlds of Yanshi was ambiguous, both being connected through the consumption of food and drink.

In the concluding chapter of our book Wilk returns to, and challenges, the notion of the materiality of food itself, highlighting the complexity of social meanings attributed to the myriad substances consumed in cuisines worldwide and through time. He skilfully weaves together the three golden threads of our volume - transformations, embodiments and symbolic consumption - and highlights the very different challenges archaeologists and anthropologist face when interrogating the materiality of food and people's engagement with foodstuffs. Wilk emphasizes the sensual embodied experiences of ingesting foods and the complex ways in which taste is culturally constituted; the notion of what is not only edible, but also 'tastes nice' has considerably impact on the transformation or conservatism of 
cuisines. He also highlights new ways that the stuff of daily life and sustenance is manipulated into a visceral pleasure and looks at various new very modern twists on the feast and symbolic consumption within capitalist societies.

\section{CONCLUDING REMARKS}

In this volume the contributors go beyond the materiality of food, to also incorporate the objects through which food comes to life both physically and symbolically. The authors consider the material culture of food and drink alongside the variety of substances consumed - and extending the notion of 'foodstuffs' to incorporate substances not typically incorporated within this category, most notably water (the stuff of life) and opium. They discuss the diverse embodied experiences of food and the differing conceptions of food and its material culture. By looking at different cultures spanning from ancient Egypt to twentieth-century Netherlands, from modern Kenya to ancient China, the interdisciplinary chapters explore the multiple entanglements of foodstuffs from gathering and harvesting through to the preparation and consumption. They explore the myriad ways that these interactions might encompass, the spirit; the body; the material world, and how this in turn can develop into ritual that creates an embodied knowledge - a knowledge that emerges from these material encounters - to shape the material culture of food. 


\section{REFERENCES}

Bennett, J. (2010) Vibrant Matter: a Political Ecology of Things. Durham, NC; London: Duke University Press.

Blake, E. (2005) 'The material expression of cult, ritual and feasting', in E. Blake and A.B. Knapp (eds) The Archaeology of Mediterranean Prehistory, 102-29. Oxford: Blackwell Publishing.

Bourdieu, P. (1972) Esquisse d'une théorie de la pratique; trans. R. Nice (1977) Outline of a Theory of Practice, Cambridge: Cambridge University Press.

Bray, T.L. (ed.) (2003) The Archaeology and Politics of Food and Feasting in Early States and Empires, New York, NY: Kluwer Academic, Plenum Publishers.

Candea, M. \& da Col, G. (2012) 'The Return to Hospitality', Journal of Royal Anthropological Institute NS: S1-S19.

Christakis, K.S. (1999) Pithoi and food storage in Neopalatial Crete: a domestic perspective. World Archaeology 31(1): 1-20. (2011) Redistribution and political economies in Bronze Age Crete. Forum: Redistribution in Aegean Palatial Societies. American Journal of Archaeology 115(1): 197-205.

Coole, D., \& C. Frost (ed.) (2010) New Materialist: Ontology, Agency and Politics, Durham, NC; London: Duke University Press Books.

Counihan, C. \& P. van Esterick (1997) 'Introduction', in C. Counihan \& P. van Esterick (eds) Food and Culture: A Reader, 1-7. London; New York, NY: Routledge.

d'Anna, M.B. (2012) 'Between inclusion and exclusion: feasting and redistribution of meals of Late Chalcolithic Arslantepe (Malatya, Turkey)', in S. Pollock (ed.) Between Feasts and Daily Meals: Toward an Archaeology of Commensal Spaces. eTopoi Journal for Ancient Studies. Special Volume 2: 97-123. Online. Available HTTP: $<$ http://journal.topoi.org/index.php/etopoi/issue/view/3> (accessed January 2016).

Dietler, M.(1996) 'Feasts and commensal politics in the political economy. Food, power and status in prehistoric Europe', in P. Wiessner \& W. Schiefenhövel (eds) Food and the Status Quest: An Interdisciplinary Perspective, 87-125. Oxford: Berghahn Books.

Dietler, M. \& B. Hayden (eds) (2001) Feasts: Archaeological and Ethnographic Perspectives on Food, Politics, and Power, Washington DC; London Smithsonian Institute. 
Hamilakis, Y. (1998) 'Eating the dead: mortuary feasting and the politics of memory in the Aegean Bronze Age societies', in K. Branigan (ed.) Cemetery and Society in the Aegean Bronze Age, Sheffield Studies in Aegean Archaeology 1, 115-32. Sheffield: Sheffield University Press.

(2008) 'Time, performance and the production of a mnemonic record: from feasting to an archaeology of eating and drinking', in L. Hitchcock, R. Laffineur \& J. Crowley (eds) DAIS, The Aegean Feast, Proceedings of the 12th International Aegean Conference, 25-29 March 2008, The University of Melbourne (Aegaeum 29), 4-18. Liège; Austin, TX: Université de Liège \& University of Texas at Austin.

Hamilakis, Y. and S. Sherratt (2012) 'Feasting and the consuming body in Bronze Age Crete and Early Iron Age Cyprus', in Parallel Lives: Ancient Island Societies in Crete and Cyprus, G. Cadogan, M. Iacovou, K. Kopaka and J. Whitley (eds), 187-207. London: British School at Athens.

Hayden, B. (1996) 'Feasting in prehistoric and traditional societies', in P. Wiessner \& W. Schiefenhövel (eds) Food and the Status Quest: An Interdisciplinary Perspective, 127-48. Oxford: Berghahn Books.

(2014) The Power of Feasts: From Prehistory to the Present, Cambridge: Cambridge University Press.

Hayden, B., N. Canuel \& J. Shanse (2012) 'What was brewing in the Natufian? An archaeological assessment of brewing technology in the Epipaleolithic', Journal of Archaeological Method and Theory 20(1): 102-50.

Hayes-Conroy, A. \& J. Hayes-Conroy (2008) 'Taking back taste: Feminism, food and visceral politics', Gender, Place \& Culture: A Journal of Feminist Geography 15(5): 461-73.

Holtzman, J.D. (2006) 'Food and Memory', in Annual Review of Anthropology 35: 361-78.

Ingold, T. (2013) Making: Anthropology, Archaeology, Art and Architecture, London: Routledge

Lavis, A. (in press) 'Imagined materialities and material imaginings: food, bodies, and the "stuff" of (not) eating in anorexia', Gastronomica.

Lupton, D. (1994) 'Food, memory and meaning: the symbolic and social nature of food events', The Sociological Review 42(4): 664-85. 
(1996) Food, the Body and the Self. London, Thousand Oaks, CA; New Delhi:

SAGE Publications.

Mauss, M. (1925) Essai sur le Don; trans. W.D. Halls (1990) The Gift: The Form and Reason for Exchange in Archaic Societies, New York, London: W.W. Norton.

McGovern, P.E. (2003) Ancient Wine: The Search for the Origins of Viniculture, Princeton, NJ: Princeton University Press. (2009) Uncorking the Past: The Quest for Wine, Beer, and Other Alcoholic Beverages, Berkeley, CA: University of California Press.

Miller, D. (1998) 'Coca-Cola: a black sweet drink from Trinidad', in D. Miller (ed.) Material Cultures: Why Some Things Matter, 169-87. Chicago: Chicago University Press.

Mintz, S.W. (1985) Sweetness and Power: The Place of Sugar in Modern History, New York, NY: Viking.

Mintz, S.W. \& C. du Bois (2002) 'The anthropology of food and eating', Annual Review of Anthropology 31: 99-119.

Miracle, P. \& N. Milner (eds) (2002) Consuming Passions and Patterns of Consumption, MacDonald Institute Monographs. Cambridge: McDonald Institute for Archaeology.

Mol, A. (2008) 'I eat an apple: on theorizing subjectivities', Subjectivity 22: 28-37.

O'Connor, K. (2015) The Never-Ending Feast: the Anthropology and Archaeology of Feasting, London: Bloomsbury.

Ryan, P., C. Cartwright \& N. Spencer (2012) 'Archaeobotanical research in a pharaonic town in ancient Nubia', The British Museum Technical Research Bulletin 6: 97-107.

Ryan, P. \& N. Spencer, N. (2013) 'Diet and plant use at Amara West', Egyptian Archaeology 42: $18-20$.

Schmandt-Besserat, D. (2001) Feasting in the ancient Near East', in M. Dietler \& B. Hayden (eds) Feasts: Archaeological and Ethnographic Perspectives on Food, Politics, and Power, 391-403. Washington DC; London Smithsonian Institute.

Steel, L. 2004. 'A goodly feast . . a cup of mellow wine: feasting in Bronze Age Cyprus', in The Mycenaean Feast, J.C. Wright (ed.). Princeton, NJ: American School of Classical Studies, 161-80. 
(in press) 'Kitchenalia in Bronze Age Cyprus', Gastronomica.

Stockhammer, P.W. (2012) 'Performing the Practice Turn in Archaeology', Transcultural Studies 1: 7-42. Online. Available HTTP: < http://heiup.uniheidelberg.de/journals/index.php/transcultural/article/view/9263> (accessed January 2016).

Sutton, D.E. (2001) Remembrance of Repasts: An Anthropology of Food and Memory, London, Oxford: Bloomsbury.

Tzedakis, Y. \& H. Martlew (eds) (1999) Minoans and Mycenaeans: Flavours of their Time, Athens.

Watson, J.L. \& M.L. Caldwell (eds) (2004) The Cultural Politics of Food and Eating: A Reader, Blackwell Readers in Anthropology 8, Oxford: Blackwell.

Wesson, C.B. (1999) 'Chiefly power and food storage in southeastern North America', World Archaeology 31(1): 145-64.

Wright, J.C. (ed.) (2004) The Mycenaean Feast, Princeton, NJ: American School of Classical Studies at Athens.

Wengrow, D. (2008) 'Prehistories of commodity branding', Current Anthropology 49: 7-34. 


\section{NOTES}

${ }^{1}$ Embodied Encounters: Exploring the Materialities of Food 'Stuffs' hosted at the University of Wales Trinity Saint David, Lampeter in May 2014 and funded by the Wenner-Gren Foundation. A follow on workshop in January further drew upon the key themes previously identified and highlighted innovative new areas of research (see for example, Attala and Zinn this volume). Other papers resulting from this workshop are published in Gastronomica 2016. ${ }^{2}$ O'Connor's recent edited volume (2015) discussing 'the archaeology and anthropology of feasting' likewise draws primarily upon archaeological rather anthropological case studies. 